Fourth International Conference on Sustainable Construction Materials and Technologies http://www.claisse.info/Proceedings.htm

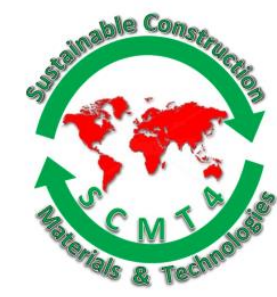

SCMT4

Las Vegas, USA, August 7-11, 2016

\title{
Rheological Characteristics of Self-Compacting Concrete Mixtures Containing Metakaolin, Ground Granulated Blast-Furnace Slag and Fly Ash
}

\author{
Sina Dadsetan ${ }^{1 \mathrm{a}}$, and Jiping Bai ${ }^{1 \mathrm{~b}}$ \\ ${ }^{1}$ Faculty of Computing, Engineering and Science, University of South Wales, CF37 1DL, UK, \\ ${ }^{1 a}$ Email: 〈Sinadadsetan@gmail.com>, ${ }^{1 b}$ Email: <jiping.bai@southwales.ac.uk>.
}

\begin{abstract}
Supplementary cementitious materials (SCMs) have been recently used in self-compacting concrete (SCC) in order to make it cost effective, better performance and also reduce the overall greenhouse gas emissions associated with the production of concrete. In this study, the rheological properties of 18 SCC mixtures with various SCMs were investigated for a constant slump flow value. In order to achieve this, Portland Cement (PC) as the main binder were replaced by various percentage of Metakaolin (MK), Ground Granulated Blast-furnace Slag (GGBS) and Fly Ash (FA) in two water/binder ratios. Results showed that MK increased high range water reducing admixture (HRWRA) demand and decreased rheological aspects due to the finer particles and also higher amount of aluminium. However the opposite tendency was observed when FA was incorporated with PC as the spherical fly ash particles makes it easier for the SCC mix to flow. Moreover, substitution of PC with GGBS increased HRWRA required in the SCC mixture having constant slump flow but no change on the other rheological properties. Scanning Electron Microscopy (SEM) and Energy dispersive X-ray spectroscopy (EDS) were used to understand the microstructural properties of SCMs.
\end{abstract}

\section{INTRODUCTION}

Self-Compacting Concrete (SCC) is a new type of high-performance concrete which is able to flow and compact under its own weight without the need of any external vibrations and also fill the formwork whilst maintaining homogeneity without any migration or separation of its large components even in the presence of congested reinforcement [BS EN 206-9 2010; The Concrete Society and BRE 2005]. Other researchers [Ozawa et al. 1989; Bartos and Marrs 1999; Khayat 1999] have defined SCC in almost the same terms as a highly flow-able concrete that should meet the requirements of flow-ability, passing ability and segregation resistance. Stability and flow ability are the main characteristics of SCC. They are achieved by limiting the coarse aggregate content, the maximum aggregate size and reducing water to powder ratios together with using superplasticizers (SP) [Okamura et al. 1998]. During the transportation and placement of SCC the enhanced flow ability may cause segregation and bleeding which can be overcome by increasing the viscosity of concrete mix, this is usually supplied by using a high volume fraction of paste, by limiting the maximum aggregate size or by using viscosity modifying admixtures (VMA) [Khayat 1999]. However, chemical admixtures are expensive and may contribute to increasing the cost of concrete. On the other hand, achieving high powder content by increasing the cement content is not reasonable, and may lead to a significant rise in material cost and some negative impacts on concrete properties associated with the rise 
in temperature during hydration and higher drying shrinkage. Alternatively, incorporating supplementary cementitious materials (SCMs) in concrete can convey many advantages to concrete through improvement of particle distribution, cohesion, and reduction of the risk of thermal cracking as well as the improvement of certain mechanical and rheological properties. SCMs have two common features; their particle size is smaller or the same as Portland cement particle and they become involved in the hydration reactions mainly because their ability to exhibit pozzolanic behaviour. By themselves, pozzolans which contain silica $\left(\mathrm{SiO}_{2}\right)$ in a reactive form, have little or no cementitious value. However, in a finely divided form and in the presence of moisture they will chemically react with calcium hydroxide at ordinary temperatures to form cementitious compounds [Lewis et al. 2003; Domone and Illston 2010]. The most common SCMs used are ground granulated blast furnace slag (GGBS), Metakaolin (MK) and pulverised fuel ash or fly ash (FA).

Adding GGBS to self-compacting concrete offers many advantages related to increasing its compactability, workability and retaining it for a longer time, while protecting cement against both sulphate and chloride attack [Russel 1997]. Because GGBS has 10\% lower density than Portland cement, replacing an equal mass of cement by GGBS will result in a larger paste volume, which substantially increases the segregation resistance and flow ability. Water demand tends to be less for concrete made with GGBS, owing to the slicker surface texture of the slag particles compared to cement, and to the delay in the chemical reaction [Lewis et al. 2003]. Oner and Akyuz [2007], in their experiments on 32 different mixtures of SCC containing GGBS, indicated that as GGBS content increases, water to binder ratio decreases for the same workability and thus GGBS has a positive effect on the workability.

Generally, it is clear that the rheological properties of SCC are expected to be affected by the addition of metakaolin, due to its physical properties. Specifically, metakaolin particles are usually finer than the particles of Portland cement and present different shape characteristics, compared to cement or filler. According to Cyr et al. [2000] and Gallias et al. [2000], particles with an irregular shape tend to more easily show a shear thickening behaviour and, therefore, an increase of the viscosity. Thus, the replacement of either the cement or the inert limestone powders that are frequently used in SCC by metakaolin is expected to significantly affect the flowability and the viscosity of the mixture [Sfikas et al. 2014].

Adding fly ash to SCC mixture can improve its rheological characteristics while reducing water demand, because of its small spherical shape [Koehler et al. 2007]. The use of fly ash and GGBS together in SCC can reduce the quantity of superplasticizer needed to obtain slump flow spread diameter as equalled with SCC made with only Portland cement [Bouzoubaa and Lachemib 2001]. Furthermore, additional studies showed that the effect of fly ash on the workability of super flowing concrete by replacing $30 \%$ of cement with fly ash can result in outstanding workability [Kim et al. 1996]. ICAR [2007] and Sonebi [2004] reported that the use of fly ash reduced both the yield stress and plastic viscosity of SCC. This is not approved by the other studies where Park et al. [2005] found that fly ash slightly reduced yield stress but increased the plastic viscosity of superplasticised pastes. Fly ash can also decrease bleeding and develop constancy [Shadle and Somerville 2002].

The main aim of this research work was to utilize three types of SCMs: metakaolin, fly ash and GGBS in SCC and to study their effect on rheology at different replacements of cement (10 and $20 \mathrm{wt} . \%$ for MK and 10, 20 and 30 wt.\% for FA and GGBS). The rheological properties were examined by conducting several tests as per The European Guidelines for Self-Compacting Concrete [2005] specifications and proper mix proportion was achieved. For better understanding of the specification of SCMs, micrographs have been taken by Scanning Electron Microscope (SEM) and Energy dispersive X-ray spectroscopy (EDS). 


\section{EXPERIMENTAL WORK}

Constituent materials. Portland cement CEM II/ B-V 32.5R type, manufactured by Lafarge Company, was used throughout this study. Fly ash used in this experiment, is classified as siliceous fly ash (aluminosilicate fly ash) or class F Fly Ash, according to BSI standards [BS EN 14227-4:2013] where the essential chemical components are silicates and aluminates. The Blaine fineness (specific surface area) of the FA sample used was $35.48 \mathrm{~m}^{2} / \mathrm{N}\left(3478 \mathrm{~cm}^{2} / \mathrm{g}\right)$. GGBS in this research comprises mainly of $\mathrm{CaO}, \mathrm{SiO}_{2}, \mathrm{Al}_{2} \mathrm{O}_{3}$ and $\mathrm{MgO}$. It has the same main chemical constituents as ordinary Portland cement, but in different proportions. The metakaolin used in this research contained $25 \%$ and $20 \%$ silicon and aluminate respectively. MetaStar 501 obtained from IMERYS Performance Minerals Company, was used in this project. According to the data sheet of IMERYS [Imerys-perfmins.com 2015], the specific gravity of the sample used was $2.5 \mathrm{~g} / \mathrm{cm}^{3}$ with the white colour. The Limestone powder was used as filler in this project. The filler was hydrated lime with $38 \%$ calcium and small soft particles. In addition to this information, a full study of EDS analysis was carried out to understand the chemical elements of each constituent material. Figure 1 shows the micrographs and Table 1 gives the chemical elements of cement, MK, FA and GGBS.

The coarse aggregate used in this research was crushed limestone aggregates. These aggregates were in one grade size of $10 \mathrm{~mm}$. The aggregate was supplied by a local quarry in UK and complied with the requirements of BS EN 12620:2002 + A1 [2008]. The sand used throughout this study was natural seadredged sand from the Bristol Channel in UK and performed in accordance with PD 6682-1 [2009] and BS EN 933-1 [2012]. ADVA Flow 340, supplied by Grace Company was used in this research as a High Range Water Reducer Admixture (HRWRA) or Superplasticizer (SP). ADVA Flow 340 (Grace Construction Products 2013) conforms to BS EN 934-2:2009+A1 [2012].

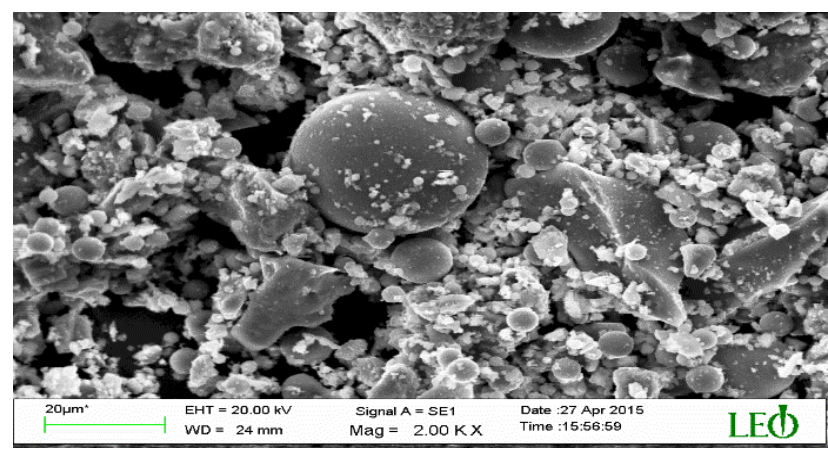

a)

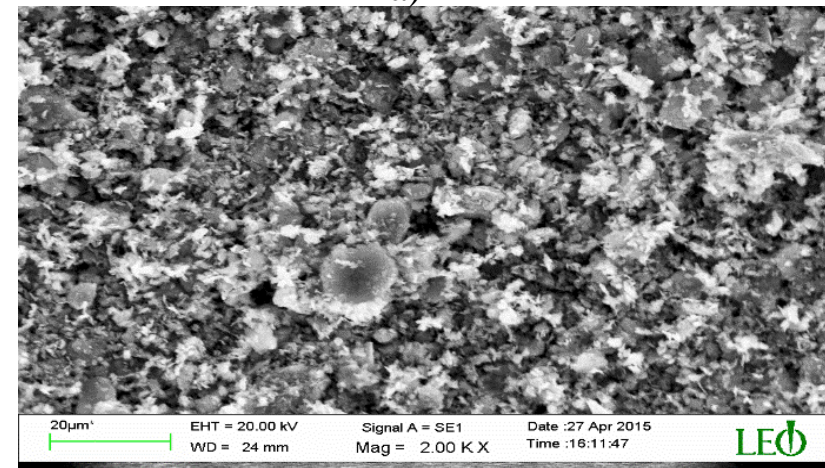

c)

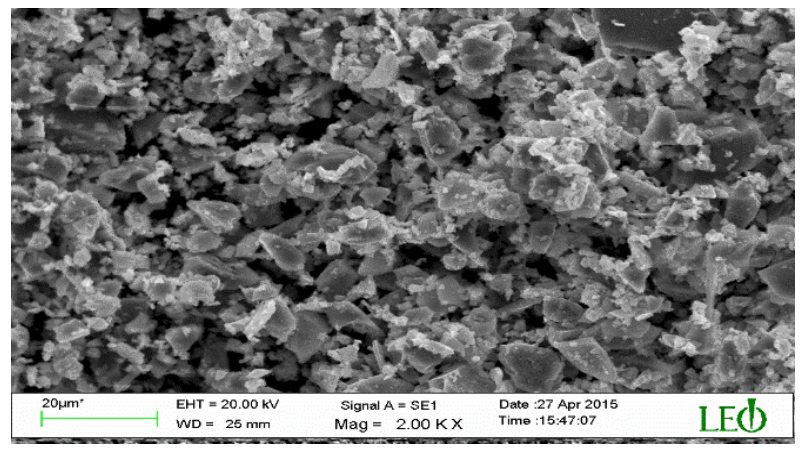

b)

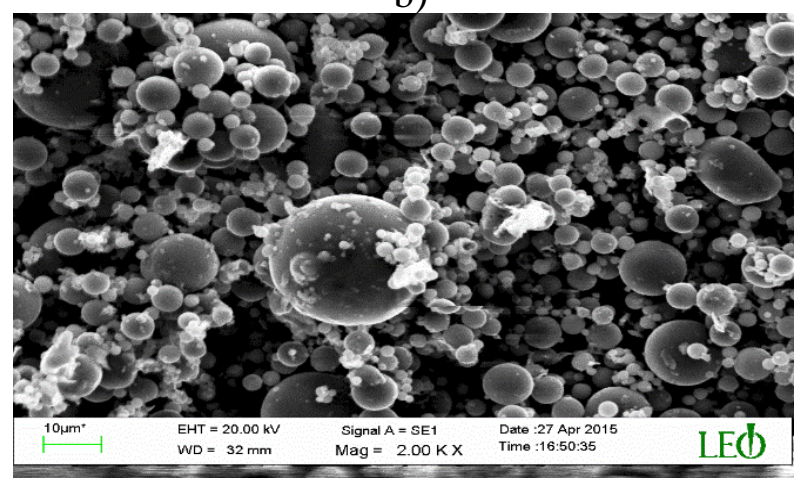

d)

Figure 1. SEM Micrographs with 2.00K Large Scale of: a) PC, b) GGBS, c) MK and d) FA 
Table 1. Chemical and Physical Properties of PC, MK, FA and GGBS

\begin{tabular}{|l|c|c|c|c|}
\hline Chemical elements \% & PC & MK & FA & GGBS \\
\hline $\mathrm{O}$ & 49.09 & 52.83 & 54.11 & 46.42 \\
\hline $\mathrm{Ca}$ & 30.10 & - & 2.06 & 27.48 \\
\hline $\mathrm{Si}$ & 9.82 & 25.45 & 24.78 & 14.80 \\
\hline $\mathrm{Al}$ & 4.88 & 20.03 & 14.92 & 4.94 \\
\hline $\mathrm{Mg}$ & 0.98 & - & 0.59 & 4.50 \\
\hline $\mathrm{K}$ & 1.04 & 1.70 & 2.25 & 0.50 \\
\hline $\mathrm{Fe}$ & 2.38 & - & 1.29 & 0.28 \\
\hline Specific gravity $\left(\mathrm{g} / \mathrm{cm}^{3}\right)$ & 3.1 & 2.5 & 2.058 & 2.9 \\
\hline
\end{tabular}

\section{Mix design method and proportions}

Mix design method, used in this research, is based on the paste volume [The European Guidelines for SelfCompacting Concrete 2005] with appropriate water/powder ratio. Water/powder ratios were kept in the range of 0.85 to 1.1 recommended by The European Guidelines for Self-Compacting Concrete [2005]. Totally, 18 SCC mixtures, with two different water/binder ratios ( 0.4 and 0.45$)$, including two normal SCC mixes and two groups of 8 mixtures with different percentage of SCMs were cast and tested. In each group, metakaolin replaces at 10 and 20 percent of weight of the normal SCC mixture's cement content. GGBS and FA also replace at 10, 20 and 30 percent of whole cement weight. Binder content was kept in a constant value of $400 \mathrm{~kg} / \mathrm{m}^{3}$ for all mixes. The mixture proportions are shown in Table 2. The amount of superplasticizer was measured after making concrete. In another way, the slump flow target was fixed on $750 \pm 20 \mathrm{~mm}$ and superplasticizer was added until satisfy the slump flow target. Therefore, the amount of superplasticizer was added to the mix designs after making concrete. The name of mix designs, shown in Table 2, is based on: 1- water to binder ratio, 2-first letter of SCMs and 3- the SCMs replacement percentage. For example: 45M10: $\mathrm{w} / \mathrm{b}=0.45,10 \%$ Metakaolin as replacements of cement

Table 2. Mix Proportions $\left(\mathrm{kg} / \mathrm{m}^{3}\right)$

\begin{tabular}{|c|c|c|c|c|c|c|c|c|}
\hline Mix code & PC & MK & GGBS & FA & Sand & Gravel & Lime & Water \\
\hline 40C & 400 & - & - & - & 802.9 & 877.2 & 89.4 & 160 \\
\hline 40M10 & 360 & 40 & - & - & 802.9 & 877.2 & 89.4 & 160 \\
\hline 40M20 & 320 & 80 & - & - & 802.9 & 877.2 & 89.4 & 160 \\
\hline 40G10 & 360 & - & 40 & - & 802.9 & 877.2 & 89.4 & 160 \\
\hline 40G20 & 320 & - & 80 & - & 802.9 & 877.2 & 89.4 & 160 \\
\hline 40G30 & 280 & - & 120 & - & 802.9 & 877.2 & 89.4 & 160 \\
\hline 40F10 & 360 & - & - & 40 & 802.9 & 877.2 & 89.4 & 160 \\
\hline 40F20 & 320 & - & - & 80 & 802.9 & 877.2 & 89.4 & 160 \\
\hline 40F30 & 280 & - & - & 120 & 802.9 & 877.2 & 89.4 & 160 \\
\hline 45C & 400 & - & - & - & 732.5 & 851.7 & 121.6 & 180 \\
\hline 45M10 & 360 & 40 & - & - & 732.5 & 851.7 & 121.6 & 180 \\
\hline 45M20 & 320 & 80 & - & - & 732.5 & 851.7 & 121.6 & 180 \\
\hline 45G10 & 360 & - & 40 & - & 732.5 & 851.7 & 121.6 & 180 \\
\hline 45G20 & 320 & - & 80 & - & 732.5 & 851.7 & 121.6 & 180 \\
\hline 45G30 & 280 & - & 120 & - & 732.5 & 851.7 & 121.6 & 180 \\
\hline 45F10 & 360 & - & - & 40 & 732.5 & 851.7 & 121.6 & 180 \\
\hline 45F20 & 320 & - & - & 80 & 732.5 & 851.7 & 121.6 & 180 \\
\hline 45F30 & 280 & - & - & 120 & 732.5 & 851.7 & 121.6 & 180 \\
\hline
\end{tabular}




\section{Rheological Properties}

The main fresh properties of SCC mixes such as deformability, passing ability and segregation resistance were analyzed by slump flow spreading diameter, J-ring step height, L-box passing ratio, U-box step height and V-funnel flow times according to the procedure recommended by The European Guidelines for SelfCompacting Concrete [2005] and EFNARC [2002]. The slump-flow test examined the first of three key properties of SCC: deformability. Throughout the laboratory testing the slump flow diameters were fixed for all mixtures within the range of $750 \pm 20 \mathrm{~mm}$. In order to do this, trial tests were undertaken to adjust the amount of superplasticizer for each mixture throughout the study. The slump flow was carried out in accordance with BS EN 12350-8 [2010]. The J-ring test was carried out in accordance with BS EN 1235012 [2010]. This test was principally used in order to determine the passing ability of the SCC, as the bars duplicate reinforcement in practical applications. The L-box test is one of the most utilized tests for assessing the passing ability of SCC to flow through tight openings and various shapes, as well as the filling ability of the concrete. The test was carried out in accordance with BS EN 12350-10 [2010]. The U-box test was developed by the Technology Research Centre of the Taisei Corporation in Japan [EFNARC 2002]. The U-box test measures the filling ability of SCC. The V-funnel test is predominately used to indicate the viscosity as well as the filling ability of the concrete sample. The V-funnel test to assess the deformability rate of SCC flowing through a confined space was undertaken in accordance with BS EN 12350-9 [2010] in two different times: 1 and 5 minutes.

\section{RESULTS AND DISCUSSIONS}

\section{Rheological Results}

To classify a concrete as self-compacting, the requirements for filling and passing ability as well as segregation resistance must be fulfilled in order to provide ease of flow when unconfined by formwork or reinforcement, and an ability to remain homogeneous in fresh state. It is specified that the filling ability and stability of self-compacting concrete in the fresh state can be defined by four key characteristics namely flow-ability, viscosity, passing ability, and segregation resistance. The results of all rheological tests are given in Table 3. The quantity of superplasticizer which were added to concrete to provide the target slump flow $(750 \pm 20 \mathrm{~mm})$ are also given in Table 3.

According to Table 3, it is clear that all SCC mixes satisfied the range of $750 \pm 20 \mathrm{~mm}$. In mixes containing metakaolin with increase in the MK replacement level the J-ring value increased compared with the control mixes for both $w / b=0.4$ and 0.45 . SCC mixes containing GGBS also show the same behavior of MK and increased the J-ring value by increasing the GGBS content. On the other hand, mixtures blended with fly ash show contradictory behavior in SCC compared with both previous MK and GGBS concrete. The J-ring values decreased with increase of fly ash content. In most cases, the step height values are zero demonstrating that fly ash can enhance the passing ability of SCC.

The L-box passing ratio decreased in MK SCC mixes compared with that of control mixes for both $\mathrm{w} / \mathrm{b}=0.4$ and 0.45. GGBS mixes showed for the replacement level higher than $20 \%$ wt the L-box passing ratio increases. Fly ash SCC mixes in all cases increased L-box passing ratio by increasing the amount of FA. This shows FA can improve the rheological characteristics due to its spherical shapes in particles. Based on U-box step height results, GGBS and MK increased the value by increasing in the replacement level from 0 to $20 \%$ for MK and 30\% for GGBS. Lower U-box step height values with FA mixtures show better rheological performance of SCC blended with FA. V-funnel passing time for $1 \mathrm{~min}$ and $5 \mathrm{~min}$ also explains the same results for GGBS, MK and FA. It is also obvious that to achieve the target slump flow value, the amount of superplasticizer has been changed for each SCC mix. MK and GGBS mixes demanded higher amount of SP, whereas FA required less SP with the increase of cement replacement level. 
Table 3. Rheological Results and the Contents of Superplasticizer

\begin{tabular}{|c|c|c|c|c|c|c|c|}
\hline \multirow[t]{2}{*}{$\begin{array}{l}\text { Mix } \\
\text { code }\end{array}$} & \multirow[t]{2}{*}{$\begin{array}{c}\text { Slump } \\
\text { flow (mm) }\end{array}$} & \multirow[t]{2}{*}{$\begin{array}{l}\text { J-ring step } \\
\text { height }(\mathrm{mm})\end{array}$} & \multirow[t]{2}{*}{$\begin{array}{l}\text { L-box passing } \\
\text { ratio }\left(\mathrm{H}_{2} / \mathrm{H}_{1}\right)\end{array}$} & \multirow[t]{2}{*}{$\begin{array}{l}\text { U-box step } \\
\text { height }(\mathrm{mm})\end{array}$} & \multicolumn{2}{|c|}{$\begin{array}{l}\text { V-funnel passing time } \\
(\mathrm{sec})\end{array}$} & \multirow[t]{2}{*}{$\begin{array}{c}\mathrm{SP} \\
\left(\mathrm{kg} / \mathrm{m}^{3}\right)\end{array}$} \\
\hline & & & & & $1 \mathrm{~min}$ & $5 \mathrm{~min}$ & \\
\hline $40 \mathrm{C}$ & 740 & 3 & 0.94 & 5 & 7 & 10 & 4.5 \\
\hline $40 \mathrm{M} 10$ & 730 & 10 & 0.89 & 10 & 10 & 15 & 8.6 \\
\hline $40 \mathrm{M} 20$ & 730 & 20 & 0.85 & 20 & 12 & 18 & 10.4 \\
\hline 40G10 & 750 & 5 & 0.92 & 5 & 6 & 11 & 5.3 \\
\hline 40G20 & 750 & 10 & 0.95 & 8 & 8 & 12 & 6.1 \\
\hline 40G30 & 750 & 15 & 0.96 & 10 & 9 & 13 & 6.5 \\
\hline 40F10 & 740 & 3 & 0.95 & 5 & 6 & 8 & 3.9 \\
\hline $40 \mathrm{~F} 20$ & 750 & 0 & 0.95 & 3 & 5 & 8 & 3.3 \\
\hline 40F30 & 750 & 0 & 0.98 & 2 & 4 & 8 & 2.6 \\
\hline $45 \mathrm{C}$ & 740 & 2 & 0.92 & 2 & 5 & 9 & 4.3 \\
\hline $45 \mathrm{M} 10$ & 760 & 5 & 0.89 & 5 & 9 & 14 & 7.9 \\
\hline $45 \mathrm{M} 20$ & 750 & 10 & 0.89 & 15 & 10 & 18 & 9.6 \\
\hline $45 \mathrm{G} 10$ & 730 & 5 & 0.91 & 3 & 6 & 10 & 4.9 \\
\hline $45 \mathrm{G} 20$ & 750 & 10 & 0.95 & 6 & 8 & 11 & 5.3 \\
\hline $45 \mathrm{G} 30$ & 770 & 10 & 0.98 & 10 & 9 & 11 & 5.8 \\
\hline $45 \mathrm{~F} 10$ & 750 & 0 & 0.94 & 4 & 4 & 6 & 3.6 \\
\hline $45 \mathrm{~F} 20$ & 750 & 0 & 0.96 & 3 & 6 & 8 & 3.1 \\
\hline $45 \mathrm{~F} 30$ & 760 & 0 & 0.98 & 1 & 7 & 7 & 2.3 \\
\hline
\end{tabular}

\section{Superplasticizer dosage}

Figure 2 shows the superplasticizer dosage for 18 SCC mixes. Figures 3 and 4 present the trend of SP demand with the increase of SCMs. In SCC mixes containing MK, superplasticizer was dramatically increased with the increase of the replacement level. This is due to the finer particles of MK compared with PC. GGBS mixes also required higher dosage of SP by increasing replacement level. FA showed contradictory results which demanded less SP quantities by increasing FA content in SCC.

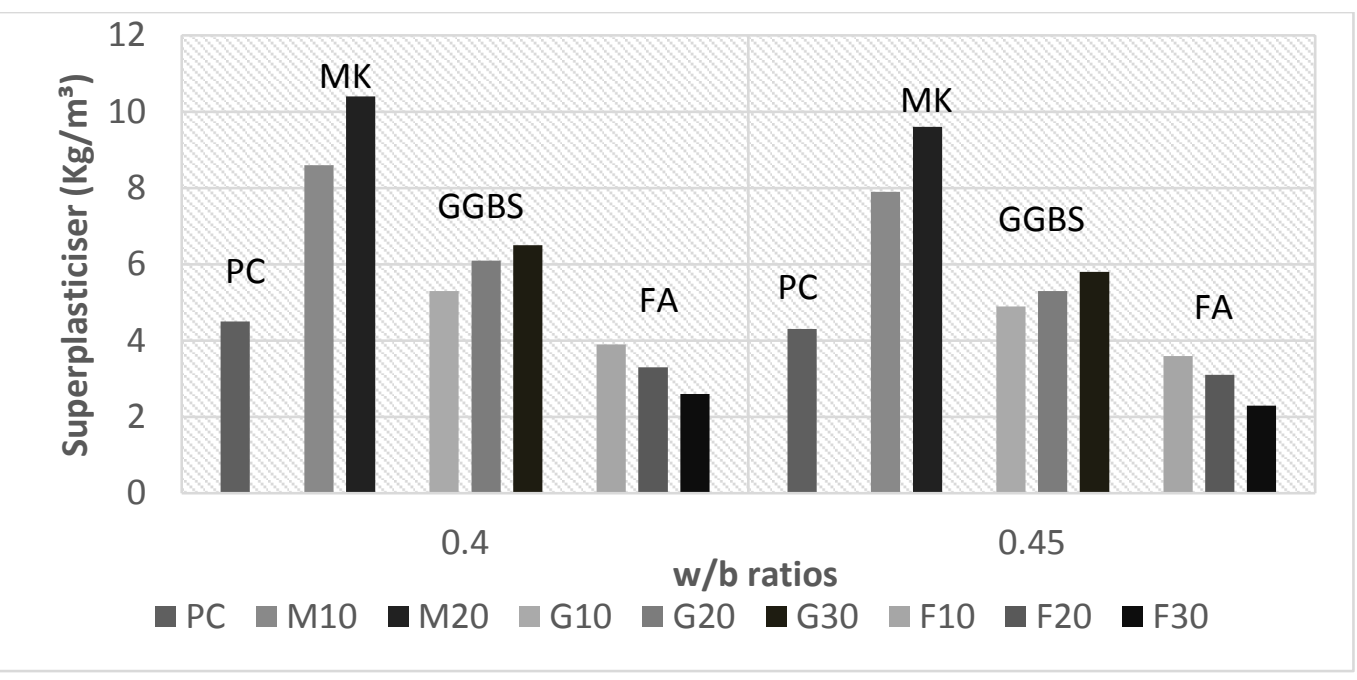

Figure 2. Superplasticer quantities $\left(\mathrm{kg} / \mathrm{m}^{3}\right)$ 


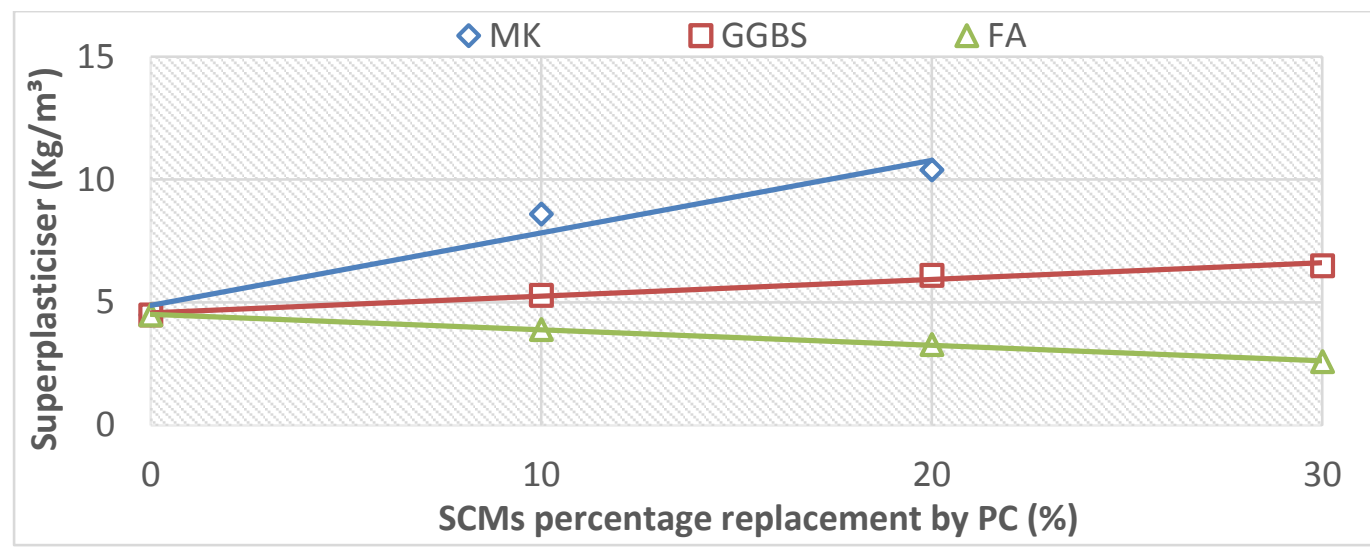

Figure 3. The Changes in Superplasticizer for each SCM with w/b=0.4

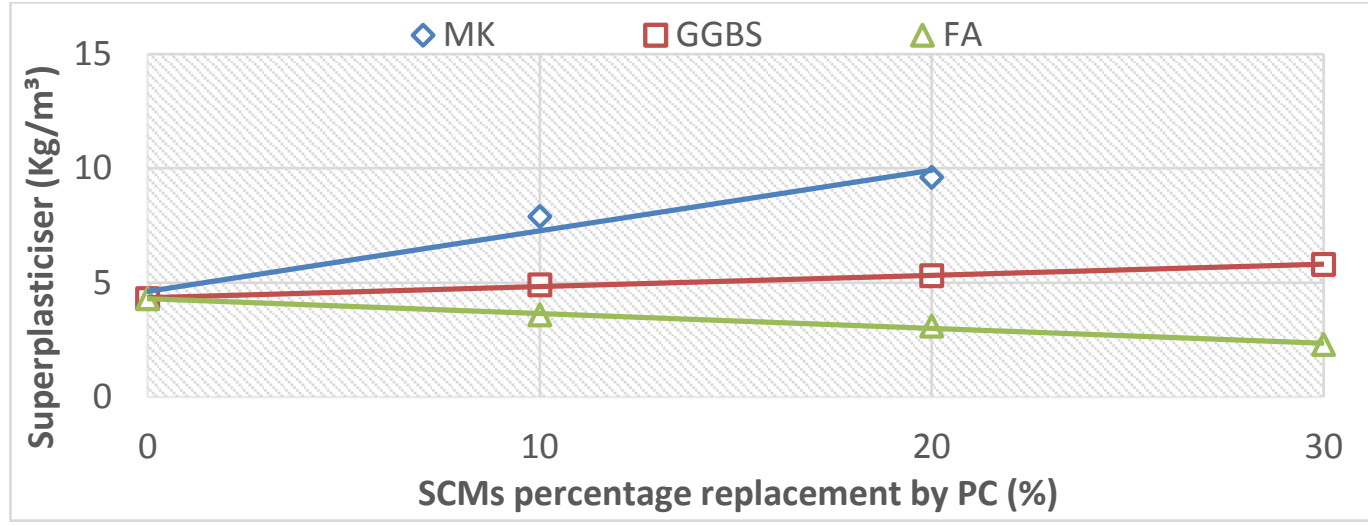

Figure 4. The Changes in Superplasticizer for each SCM with $w / b=0.45$

Relationship between L-box, U-box and V-funnel. Figures 5, 6 and 7 demonstrate the close relationships between L-box and U-box with V-funnel for all mixtures blended with MK, GGBS and FA, respectively. Though each regression trend line gives different correlation coefficients, they demonstrate a useful way to adjust dosage of SP and SCM replacement level to achieve satisfactory values of L-box, U-box and V-funnel. As shown in Figure 5, in SCC mixtures blended with $\mathrm{MK}$ and for both $\mathrm{w} / \mathrm{b}$ ratios by increasing in MK content and V-funnel passing time, the Lbox passing ratio decreased and U-box step height increased, respectively. This confirms that Metakaolin enhances viscosity which can increase the V-funnel passing time and U-box step height. However, L-box passing ratio shows reverse function which decreased in passing ratio. In SCC mixtures blended with GGBS shown in Figure 6, all rheological tests increased in values by increasing GGBS content. In Figure 7, V-funnel passing ratio decreased by increasing in FA content. This is due to the spherical shapes of FA (shown in Figure 1-d) which can dramatically improve deformability of SCC. This is also confirmed by having a look in L-box and U-box results. L-box passing ratio increased which shows better passing ability and U-box step height decreased which shows better deformability. The equations shown in Figures 5, 6 and 7 can also help to predict the rheological values by having one of them. 


\section{CONCLUSION}

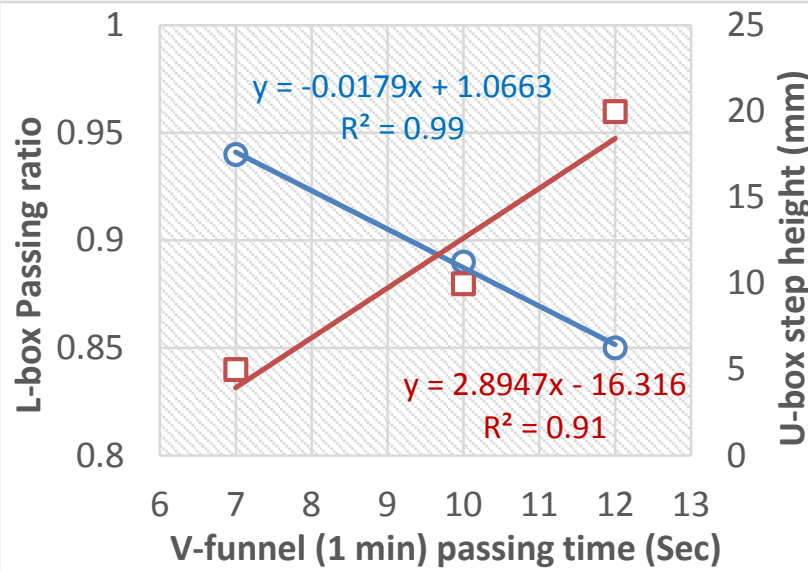

a)

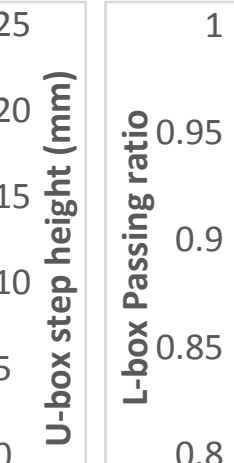

0.8

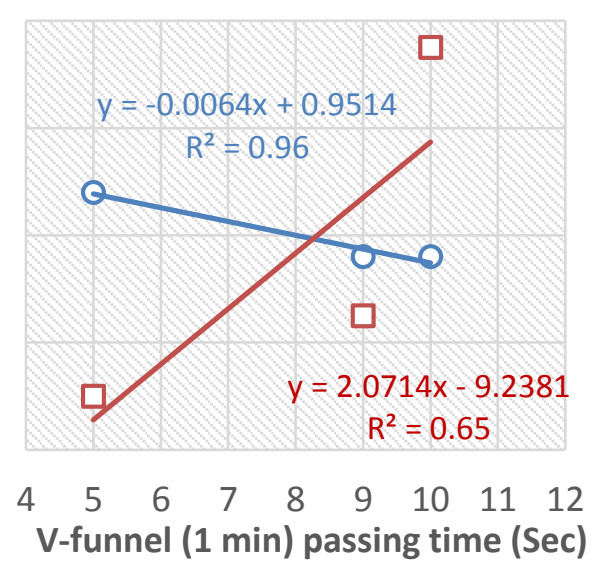

b)

Figure 5. Relationship between L-box (blue-circle) and U-box (red-square) values and Vfunnel passing time for MK mixes with: a) $w / b=0.4$ and $b$ ) $w / b=0.45$

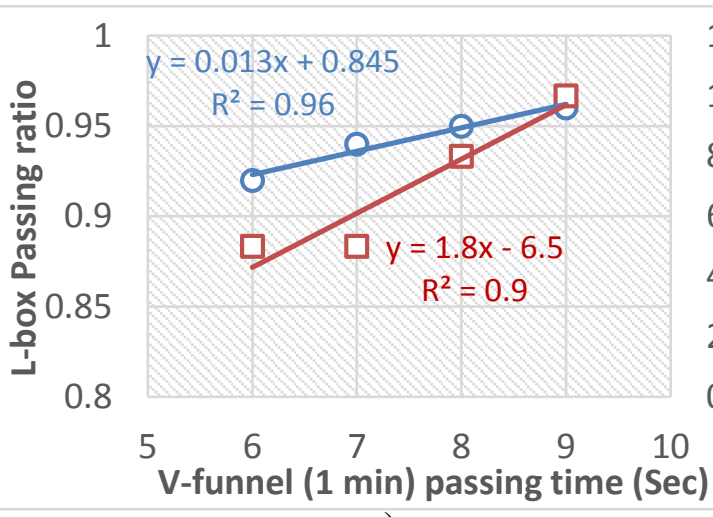

a)

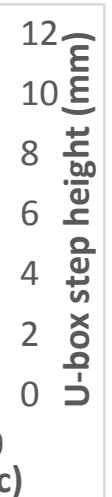

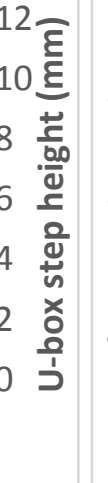

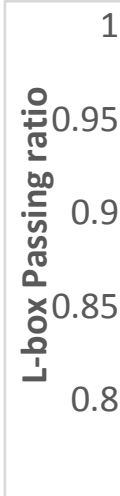

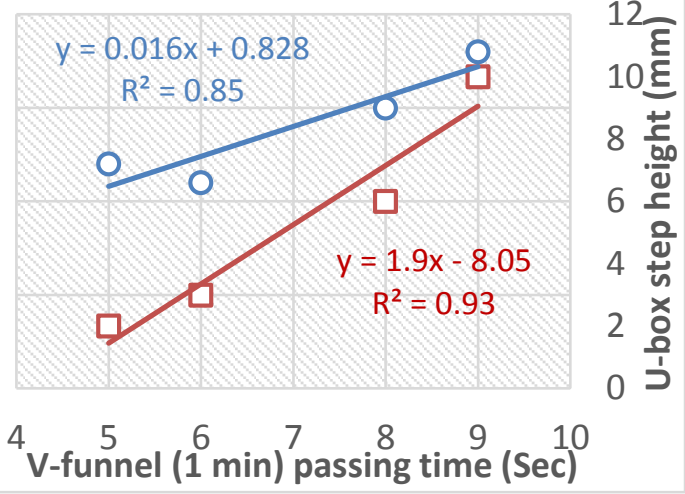

b)

Figure 6. Relationship between L-box (blue-circle) and U-box (red-square) values and Vfunnel passing time for GGBS mixes with: a) $w / b=0.4$ and b) $w / b=0.45$

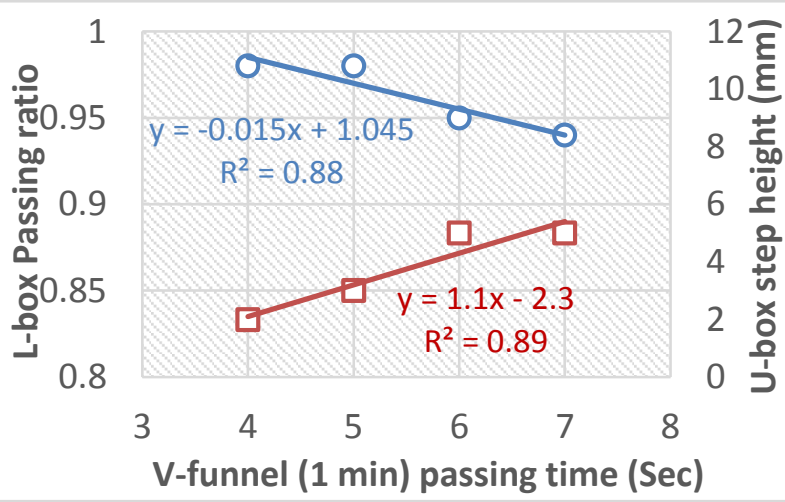

a)

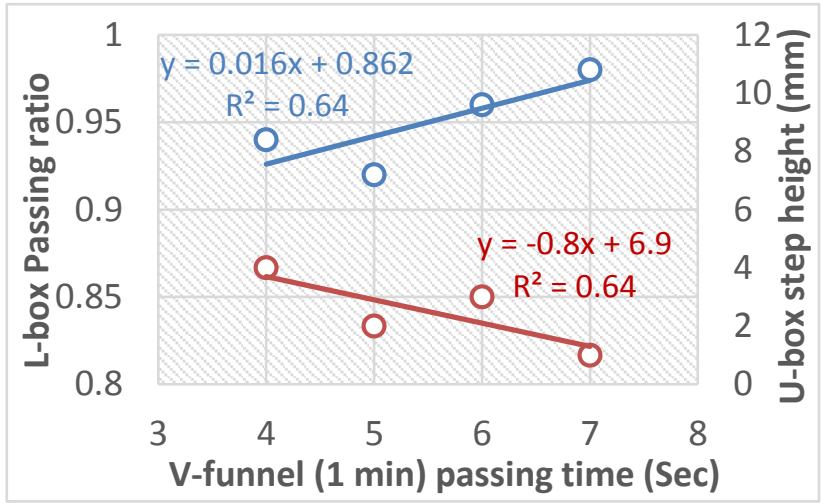

b)

Figure 7. Relationship between L-box (blue-circle) and U-box (red-square) values and Vfunnel passing time for FA mixes with: a) $w / b=0.4$ and $b$ ) $w / b=0.45$ 
The main conclusions from the present study can be drawn as follows:

- All mixtures blended with SCMs achieved slump flow diameters of $750 \pm 20 \mathrm{~mm}$, as classified between SF2 and SF3 according to European Guideline for SCC [2005].

- The new method of mix design presented in this study is appropriate for European materials and can be used to design mixtures with enough viscosity and cohesion of paste in SCC.

- Up to $20 \%$ of MK and 30\% of GGBS or FA replacement to cement could be achieved for SCC with satisfactory rheological properties.

- With the increase of MK replacement level higher amount of superplasticizer is required in SCC. This behavior is due to the finer particles and higher amount of aluminum of MK compared with PC. GGBS also increases the quantity of superplasticizer but not as much as that in MK mixtures. Fly ash mixtures demand the least quantity of SP due to the spherical particles in the microstructure.

- Increase in MK content may risk unacceptable rheological properties especially passing ability. This is because of the higher cohesion of paste and viscosity which leads to segregation in most cases. It was found in this study that up to $20 \%$ of cement replacement by MK gives optimum rheological performance.

- SCC mixtures blended with GGBS show better performance except in V-funnel passing time which increased by increasing in GGBS content. However, FA improved all rheological properties due to its spherical shapes.

- The close relationships between L-box and U-box with V-funnel for all mixtures blended with SCMs were presented. The correlations could be used as a useful way to adjust dosage of SP and SCM replacement level to achieve satisfactory values of L-box, U-box and V-funnel.

\section{REFERENCES}

Bartos, P. J. M., Marrs, D. L., (1999). Development and testing of self-compacting grout for the production of SIFCON. In Proceedings of international workshop on high performance fibre reinforced cement composites, Reinhardt, H. W. and, Maaman, A. E. (eds), Germany, pp. 171-180.

Bouzoubaa, N., Lachemib, M., (2001). Self-compacting concrete incorporating high-volumes of class F fly ash: preliminary results. Cement and Concrete Research, 31(3), pp. 413-420.

British Standard Institution, (2002). Aggregates for concrete. London: British Standard Institution. (BS EN 12620:2002 + A1: 2008)

British Standard Institution, (2009). Aggregates. Aggregates for concrete. Guidance on the use of BS EN 12620. London: British Standard Institution. (PD 6682-1:2009+A1:2013)

British Standard Institution, (2010). Concrete, Part 9: Additional rules for self-compacting concrete (SCC). London: British Standard Institution. (BS EN 206-9:2010)

British Standard Institution, (2010). Testing fresh concrete. Self-compacting concrete. Slump-flow test. London: British Standard Institution. (BS EN 12350-8:2010)

British Standard Institution, (2010). Testing fresh concrete. Self-compacting concrete. J-ring test. London: British Standard Institution. (BS EN 12350-12:2010)

British Standard Institution, (2010). Testing fresh concrete. Self-compacting concrete. L box test. London: British Standard Institution. (BS EN 12350-10:2010)

British Standard Institution, (2010). Testing fresh concrete. Self-compacting concrete. V-funnel test. London: British Standard Institution. (BS EN 12350-9:2010)

British Standard Institution, (2012). Admixtures for concrete, mortar and grout. Concrete admixtures. Definitions, requirements, conformity, marking and labelling. London: British Standard Institution. (BS EN 934-2:2009+A1:2012) 
British Standard Institution, (2012). Tests for geometrical properties of aggregates. Determination of particle size distribution. Sieving method. London: British Standard Institution. (BS EN 933-1:2012)

British Standard Institution, (2013). Hydraulically bound mixtures. Specifications. Fly ash for hydraulically bound mixtures. London: British Standard Institution. (BS EN 14227-4:2013)

Cyr, M., Legrand, C. and Mouret, M. (2000). Study of the shear thickening effect of superplasticizers on the rheological behaviour of cement pastes containing or not mineral additives. Cement and Concrete Research, 30(9), pp.1477-1483.

Domone, P. L, Illston, J. M., (2010). Construction Materials: Their Nature and Behaviour. 4th ed. Taylor and Francis Publication, ISBN. 041546515X, pp.590.

EFNARC, (2002). Specification and guidelines for self-compacting concrete. European Federation of Producers and Applicators of Specialist Products for Structures

Gallias, J., Kara-Ali, R. and Bigas, J. (2000). The effect of fine mineral admixtures on water requirement of cement pastes. Cement and Concrete Research, 30(10), pp.1543-1549.

Grace Construction Products, ADVA Flow 340 Data Sheet (2013). [Online] Available at: https://gcpat.com/construction/en-gb/concrete-technology/ADVAFlow-340 [Accessed: 17 March 2016].

ICAR, (2007). Final Report-Project 108: Aggregates in Self-Consolidating Concrete, Aggregates Foundation for Technology, Research, and Education (AFTRE). International Centre for Aggregates Research (ICAR). The University of Texas at Austin. March 2007

Imerys-perfmins.com, (2015). MetaStar 501 | Pozzolan. [online] Available at: http://www.imerysperfmins.com/eu/ProductDetail.asp?PID=92 [Accessed 13 Dec. 2015]

Khayat, K. H., (1999). Workability, testing, and performance of self-consolidating concrete. ACI Materials Journal, 96(3), pp. 339-346.

Kim, J. K., Han, S. H., Park, Y. D., Noh, J. H., Park, C. L., Kwon, Y. H. and Lee, S. G., (1996), Experimental research on the material properties of super flowing concrete, In: Bartos P. J. M., Marrs, D. L., Cleland, D. J. (eds), Production Methods and Workability of Concrete, E\&FN Spon, pp.271-284

Koehler, E. P., Fowler, D. W., Foley, E. H., Rogers, G. J., Watanachet, S., Jung, M. J., (2007). SelfConsolidating Concrete for Precast Structural Applications: Mixture Proportions, Workability, and Early-Age Hardened Properties, Aggregates Foundation for Technology: Research and Education, University of Texas, Austin, CTR Technical Report: 0-5134-1, pp.348.

Lewis, R., Sear, L., Wainwright, P., Ryle, R., (2003). Advanced Concrete Technology- Constituent Materials, Cementitious additions. Newman, J. and Choo, B.S. (Eds). Oxford: Elsevier Ltd, pp. 96-159.

Okamura, H., Ouchi, M., Hibino, M., Ozawa, K., (1998). A rational mix-design method for mortar in selfcompacting concrete. In the 6th East Asia-Pacific Conference on Structural Engineering and Construction, Taipei, ROC, 2, pp. 1307-1312.

Oner, A., Akyuz, S., (2007). An Experimental Study on optimum usage of GGBS for the compressive strength of concrete. Cement and Concrete Composites, 29(6), pp. 505-514.

Ozawa, K., Maekawa, K., Kunishima, M., Okamura, H., (1989). Development of high performance concrete based on the durability design of concrete structures. Proceedings of the 2nd East-Asia and Pacific Conference on Structural Engineering and Construction (EASEC-2), 1, pp. 445-450.

Park, C. K., Noh, M. H., Park, T. H., (2005). Rheological Properties of Cementitious Materials Containing Mineral Admixtures. Cement and Concrete Research, 35(5), pp. 842-849. 
Russel, W. B., (1997). High performance concrete-from buildings to bridges. Concrete International, 19(8), pp. 62-63.

Sfikas, I., Badogiannis, E. and Trezos, K. (2014). Rheology and mechanical characteristics of selfcompacting concrete mixtures containing metakaolin. Construction and Building Materials, 64, pp.121129.

Shadle, R., Somerville, S., (2002). The Benefits of Utilizing Fly Ash in Producing Self-Compacting Concrete. In 1st North American Conference on the Design and Use of Self-Consolidating Concrete, Chicago, pp. 217-222

Sonebi, M., (2004). Medium Strength Self-Compacting Concrete Containing Fly Ash: Modeling Using Statistical Factorial Plans. Cement and Concrete Research, 34(7), pp. 1199-1208.

The Concrete Society, BRE. (2005). Technical report No.62 self-compacting concrete: a review. Day RTU, Holton IX, editors, Camberley, UK, Concrete Society, Surrey GU17 9AB, UK.

The European Guidelines for Self-Compacting Concrete, -Specification, Production and Use, May 2005 